Discussion Paper No. 02-42

What's Spurious, What's Real?

Measuring the Productivity Impacts of ICT at the Firm-Level

Thomas Hempell

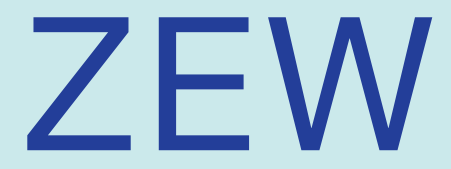

Zentrum für Europäische Wirtschaftsforschung GmbH

Centre for European

Economic Research 
Discussion Paper No. 02-42

\title{
What's Spurious, What's Real? Measuring the Productivity Impacts of ICT at the Firm-Level
}

\author{
Thomas Hempell
}

Download this ZEW Discussion Paper from our ftp server:

ftp://ftp.zew.de/pub/zew-docs/dp/dp0242.pdf

Die Discussion Papers dienen einer möglichst schnellen Verbreitung von neueren Forschungsarbeiten des ZEW. Die Beiträge liegen in alleiniger Verantwortung der Autoren und stellen nicht notwendigerweise die Meinung des ZEW dar.

Discussion Papers are intended to make results of ZEW research promptly available to other economists in order to encourage discussion and suggestions for revisions. The authors are solely responsible for the contents which do not necessarily represent the opinion of the ZEW. 


\section{Non-technical summary}

The rapidly increasing investment in information and communication technologies (ICT) and the fast diffusion of the internet during the past decade have entailed widespread hopes about a 'New Economy' ensuring large productivity gains and persistent output growth. Only the more recent economic downturn and the breakdown of once highly praised businesses have put these hopes into perspective.

In order to get a more robust picture of the productivity effects of ICT, the potential insights from using aggregate statistics have turned out to be limited. The growth of real output of the most intensive ICT-using industries, like the service sector, is frequently understated by official statistics due to problems in accounting for quality changes appropriately. Moreover, aggregate statistics contain little information about complementary efforts by firms, like organizational changes and process re-engineering, which have been found to be important accompanying efforts for a productive use of the new technologies.

Consequently, the empirical literature on the productivity impacts of ICT has been increasingly focussing on evidence at the firm-level. Since the mid 1990s, most of these studies have found evidence of significant productivity contributions of ICT. The quantitative results of these studies, however, differ to a large extent. These differences are not only due to varying samples of firms and to diverse definitions of ICT capital but also due to differences in the quantitative techniques that have been employed.

In this paper, the importance of choosing the right methodological approach is explored in more detail. A variety of interfering factors like differing management abilities, measurement errors, simultaneity of input and output decisions by firms as well as business cycles may lead to distortions in the quantitative results. These effects are illustrated by applying different econometric techniques to a representative sample of observations from German service firms over the period from 1994 to 1999. The empirical analysis yields evidence that, once all the mentioned interfering influences are controlled for, ICT is found to have enhanced productivity in German services. However, these effects are substantially smaller than those obtained in various existing studies on the topic. 


\title{
What's Spurious, What's Real? Measuring the Productivity Impacts of ICT at the Firm-Level ${ }^{\S}$
}

\author{
Thomas Hempell \\ Centre for European Economic Research (ZEW), Mannheim
}

July 2002

\begin{abstract}
In order to assess the productivity effects of information and communication technologies (ICT), regressions based on cross-sectional firm-level data may yield unreliable results for the commonly employed production function framework. In this paper, various estimation biases and econometric strategies to overcome their sources are discussed. The effects are illustrated on the basis of a representative set of panel data for German service firms. The application of a suited SYS-GMM estimator yields evidence for significant productivity effects of ICT which are substantially smaller though than those suggested by cross-section or pooled OLS estimates.
\end{abstract}

Keywords: Productivity, Information and Communication Technologies, Production Function Estimation, Panel Data, Services

JEL-Classification: C23, C81, D24, L80

Address: Centre for European Economic Research (ZEW)

Research Group of Information and Communication Technologies

P.O. Box 103443

D-68034 Mannheim

Germany

Phone: $\quad+49 / 621 / 1235-233$

Fax: $\quad+49 / 621 / 1235-225$

E-Mail: hempell@zew.de

$\S$ I would like to thank Irene Bertschek, Georg Licht, Werner Smolny, Kevin Stiroh and Elke Wolf for helpful comments and discussions and the MIP-team for providing me with the data. This paper draws on results from an ongoing research project commissioned by the Landesstiftung Baden-Württemberg foundation. 


\section{Introduction}

Like many other important inventions in history, the rapid technological progress of the semiconductor industry and the fast expansion of the internet evoked high expectations about their impact on productivity and growth. The adoption and diffusion of information and communication technologies (ICT) were expected to boost productivity substantially. However, for a long time, anecdotal evidence of computerized workplaces did not show up in aggregate productivity statistics, which had led to the proclamation of the 'productivity paradox' of ICT. 1 While investment in ICT started to grow rapidly in the U.S. since the 1970s, labour productivity growth slowed down substantially and remained at a low level until the beginning of the 90s (Jorgenson and Stiroh, 1995). The service sector was at the heart of this paradox. Around 1990, the U.S. service sector accounted for nearly 80 percent of total IT investment in the U.S. but experienced productivity growth only slightly above zero (Brynjolfsson and Yang, 1996).

One important reason for the 'productivity paradox' may well have been that aggregate statistics do not adequately reflect quality changes. This seems particularly true for the service sector in which ICT investment has evolved most dynamically. ${ }^{2}$ Only more recent studies based on aggregate statistics have found evidence for a productive role of ICT use within the overall economy ${ }^{3}$ By contrast, the advantage of firm-level studies is that the results are much less dependent on appropriate deflators. ICT investment will affect a firm's performance relative to its competitors either by decreasing costs via more efficient processes or through increasing revenues by higher product quality and prices. These effects can be captured by settling the analysis at the firm-level.

Yet another, and potentially more important, disadvantage of aggregate-type is that it is very difficult to identify the underlying determinants of a successful implementation of ICT. Not only since the emerging disillusions about a 'New Economy' since 2000, it has been recognized that ICT are far from being a panacea that yields permanent growth and the end of business cycles. In order to get a clearer picture of how ICT may actually improve business performance and which policies are best suited to foster a successful adaption of ICT, it is important to understand through which channels the use of ICT affects the success within firms.

At the end of the 1990s, a broad variety of empirical studies have emerged exploring the productivity impacts of ICT at the firm-level ${ }^{4}$ Most of these studies employ a production function framework to estimate the elasticity of output with respect to ICT capital. The elasticities found

\footnotetext{
${ }^{1}$ The productivity paradox is often linked to the famous statement by Robert Solow who summarized the scepticism about the benefits of ICT as early as in 1986 by saying that "[w]e can see the computer age everywhere but in the productivity statistics" (Uchitelle, 2000).

${ }^{2}$ See Griliches (1994) and Brynjolfsson and Yang (1996).

${ }^{3}$ Examples are studies by Schreyer (2000) and Colecchia and Schreyer (2001) for various OECD countries and an industry-level study by Stiroh (2001) for the U.S.

${ }^{4}$ See for example studies by Bertschek and Kaiser (2001), Biscourp et al. (2002), Black and Lynch (2001), Bresnahan et al. (2002), Brynjolfsson and Hitt (1995, 1996, 1998, 2000a, 2000b), Brynjolfsson and Yang (1999), Greenan and Mairesse (1996), Greenan et al. (2001), Lehr and Lichtenberg (1999), Licht and Moch (1999), Lichtenberg (1995).
} 
in these studies vary to a large extent due to differences in the definition or construction of ICT stocks, in the industries and firm-size under investigation, and due to country-specific differences. Moreover, the results are very much dependent on the quantitative methods employed. ${ }^{5}$ Various interfering influences like firm-specific effects, simultaneity of input and output decisions, measurement errors, omitted variables and the influence of business cycles may induce serious biases in the empirical analysis. The main aim of this paper is to explore these influences subsequently and to present econometric strategies that are suited to reveal the 'real' rather than spurious productivity effects resulting from the use of ICT. In addition, calibration suggestions are made about how existing firm-level data bases containing information on sales, employment and investment can be transformed adequately for the purpose of the corresponding production function estimates.

The empirical application illustrating the effects of different estimation techniques is based on a sample of more than 1100 firms from a representative survey in the German business-related and distribution service sector covering the period 1994 to 1999. Beyond analyzing the methodological issues, the study aims to present evidence on the so far hardly explored productivity impacts of ICT use on German businesses. ${ }^{6}$

The paper is organized as follows. In section 2, the theoretical and methodological issues are discussed. Section 3 gives an overview of the employed data from the Mannheim Innovation Panel in the Service Sector (MIP-S) and describes the calibrations applied to construct different stock values for ICT and conventional capital separately. Section 4 discusses the econometric issues and presents the empirical results for the ICT-extended production function framework. Section 5 concludes with a summary of the main findings.

\section{Theoretical and Methodological Issues}

In the empirical literature, the most frequently used framework for analyzing the productivity impacts of ICT has been to use a production function setup with ICT capital entering as an additional production input. ${ }^{7}$ In most studies based on aggregate data, the corresponding elasticities are determined rather indirectly applying growth accounting approaches, ${ }^{8}$ whereas firm-level (and sometimes industry-level) studies usually take advantage of the more numerous units of observations

\footnotetext{
${ }^{5}$ See for example Brynjolfsson and Hitt (1995).

${ }^{6}$ To the knowledge of the author, the only related study are cross-section analyses by Licht and Moch (1999) and Bertschek and Kaiser (2001).

${ }^{7}$ The most frequently applied proxies for ICT capital applied are the value of computers installed, book values of office, computing and accounting machinery (OCAM) from balance sheets and investment in ICT.

${ }^{8}$ The growth accounting approach aims to assign the contribution of growth of different inputs to the overall growth of output. The residual in output growth that is not explained by the growth of the observed inputs is interpreted as a rise in multifactor productivity (MFP). The approach is based on the assumption of constant returns to scale and perfect competition, such that the elasticities of output with respect to the different inputs equal the income shares of the corresponding inputs. The direct growth contribution of ICT to output growth are calculated as the product of the share of ICT capital services in total income and the growth of ICT capital stock. Potential spill-overs (not necessarily from ICT-use only, however) are captured by an increase in the residual MFP. For further details on the growth accounting within the particular context of ICT, see for example Schreyer (2000).
} 
by directly estimating the elasticities in econometric approaches. In this section, the analysis of ICT productivity within the Cobb-Douglas and the translog production function framework is briefly described and the particular advantages of firm-level analyses are summarized.

The Cobb-Douglas production function setup is expressed as:

$$
Y_{i t}=F\left(A_{i t}, L_{i t}, I C T_{i t}, K_{i t}\right)=A_{i t} L_{i t}^{\gamma_{1}} I C T_{i t}^{\gamma_{2}} K_{i t}^{\gamma_{3}}
$$

where $Y_{i t}$ is value added of firm $i$ in period $t, L_{i t}$ represents labour input, $I C T_{i t}$ and $K_{i t}$ are the corresponding amounts of ICT and conventional (non-ICT) capital respectively, and $A_{i t}$ is the multifactor productivity of firm $i .^{9}$

In an extended version of the equation, effective work force $L$ is assumed to be determined not only by the number of employees $N$ but also by its skill structure. For this purpose, the workforce is classified according to employees that are high skilled $N_{h}$ (with university degree or equivalent), medium skilled $N_{m}$ (with vocational training), and low skilled $N_{l}$ (without formal education). With $\theta_{h}$ and $\theta_{m}$ denoting the productivity differential of high and medium skilled workers compared to the average productivity of low-skilled workers, effective labour input is defined as:

$$
\begin{aligned}
L_{i t} & =N_{l, i t}+\theta_{m} \cdot N_{m, i t}+\theta_{h} \cdot N_{h, i t} \\
& =N_{i t} \cdot\left(1+\theta_{m} \cdot s_{m, i t}+\theta_{h} \cdot s_{h, i t}\right)
\end{aligned}
$$

with $s_{m, i t}=N_{m, i t} / N_{i t}$ and $s_{h, i t}=N_{h, i t} / N_{i t}$ denoting the shares of medium- and high-skilled employees in total workforce of the firms respectively. Inserting equation (2) into (1) and taking logs yields:

$$
\ln Y_{i t}=\ln A_{i t}+\gamma_{1} \ln N_{i t}+\gamma_{1} \ln \left(1+\theta_{m} s_{m, i t}+\theta_{h} s_{h, i t}\right)+\gamma_{2} \ln I C T_{i t}+\gamma_{3} \ln K_{i t}+\epsilon_{i t}
$$

With small values for $\theta_{m}, \theta_{h}, s_{m, i t}$ and $s_{h, i t}$, the term controlling for the skill structure may be simplified to: 10

$$
\ln \left(1+\theta_{m} s_{m, i t}+\theta_{h} s_{h, i t}\right) \approx \theta_{m} s_{m, i t}+\theta_{h} s_{h, i t}
$$

Inserting eq. (4) into (3) yields the following empirical model:

$$
\ln Y_{i t}=\ln A_{i t}+\gamma_{1} \ln N_{i t}+\gamma_{2} \ln I C T_{i t}+\gamma_{3} \ln K_{i t}\left[+\beta_{1} s_{m, i t}+\beta_{2} s_{h, i t}\right]+\epsilon_{i t}
$$

with $\beta_{1}=\gamma_{1} \theta_{m}$ and $\beta_{2}=\gamma_{1} \theta_{h}$. The term in square brackets denotes the additional terms from including the skill structure into the simple Cobb-Douglas production function according to

\footnotetext{
${ }^{9} F(\bullet)$ may be such that $\mathrm{Y}$ exhibits constant returns to scale in $\mathrm{K}$ and $\mathrm{L}\left(\gamma_{1}+\gamma_{2}+\gamma_{3}=1\right)$, but not necessarily.

${ }^{10}$ Anticipating some of the results and applying mean shares from the sample, the implicit products $\beta_{1} s_{m, i t} \cong 0.243$ and $\beta_{2} s_{h, i t} \cong 0.402$ yield rather high values that make the approximation very inaccurate. Since the specific values of $\theta$ are not the main interest of this study, however, this approximation may still appear appropriate.
} 
equation (1). As it is well-known, the coefficients $\gamma_{j}$ correspond to the elasticity of output with respect to the input $j$. One disadvantage of the Cobb-Douglas production function is, however, that the elasticities of the individual inputs are restricted to be constant and the elasticity of substitution between the individual inputs is restricted to one. A more flexible specification is the translog-function (Christensen and Jorgenson, 1969) in which both the output elasticities and the elasticities of substitution may vary. The translog-extension of equation (5) is:

$$
\begin{aligned}
\ln Y_{i t}= & \ln A_{i t}+\gamma_{1} \ln L_{i t}+\gamma_{11}\left(\ln L_{i t}\right)^{2}+\gamma_{2} \ln I C T_{i t}+\gamma_{22}\left(\ln I C T_{i t}\right)^{2} \\
& +\gamma_{3} \ln K_{i t}+\gamma_{33}\left(\ln K_{i t}\right)^{2}+\gamma_{12}\left(\ln L_{i t}\right)\left(\ln I C T_{i t}\right) \\
& +\gamma_{13}\left(\ln L_{i t}\right)\left(\ln K_{i t}\right)+\gamma_{23}\left(\ln I C T_{i t}\right)\left(\ln K_{i t}\right)
\end{aligned}
$$

To keep the model tractable, it is abstracted from the skill level in this specification. The elasticity of output with respect to input $j\left(\alpha_{j}\right)$ depends on the levels of all the inputs employed. For comparability to the Cobb-Douglas framework, they may be evaluated at the means of the corresponding logarithmic values (denoted by a bar). The implicit elasticities are then given by:

$$
\begin{aligned}
\bar{\alpha}_{L} & =\partial \ln Y_{i t} / \partial \ln L_{i t}=\gamma_{1}+2 \gamma_{11} \overline{\ln L_{i t}}+\gamma_{12} \overline{\ln I C T_{i t}}+\gamma_{13} \overline{\ln K_{i t}} \\
\bar{\alpha}_{I C T} & =\partial \ln Y_{i t} / \partial \ln I C T_{i t}=\gamma_{2}+2 \gamma_{22} \overline{\ln I C T_{i t}}+\gamma_{12} \overline{\ln L_{i t}}+\gamma_{23} \overline{\ln K_{i t}} \\
\bar{\alpha}_{K} & =\partial \ln Y_{i t} / \partial \ln K_{i t}=\gamma_{2}+2 \gamma_{33} \overline{\ln I C T_{i t}}+\gamma_{13} \overline{\ln L_{i t}}+\gamma_{23} \overline{\ln I C T_{i t}}
\end{aligned}
$$

As pointed out by Brynjolfsson (1994) and Licht and Moch (1999), quality improvements in particular improved customer service — are an especially important goal for ICT investment decisions. Moreover, Griliches (1994) shows that the problem of unmeasured quality improvements is especially important in the case of 'unmeasurable' services like trade and F.I.R.E. (finance, insurance, real estate) where ICT investment has grown most rapidly. As a consequence, the contribution of ICT to real output growth inferred from aggregate data are likely to be biased towards zero. For applications to firm-level data, this problem will be less severe. If a firm invests in ICT in order to improve the quality of a product while its competitors continue to offer their old products, the innovating firm will try to charge a higher price for its new product. If the quality improvement is approved by customers, they will in fact be willing to pay a higher price for the good and the value added of the innovating firm will increase accordingly. Consequently, Brynjolfsson and Hitt (2000a) argue that microeconomic studies will capture this effect and variations in output quality will contribute to measuring a higher output elasticity of ICT investment. This relationship is independent of the price deflator employed for the corresponding industry. 11

\footnotetext{
${ }^{11}$ A firm level study by Brynjolfsson and Hitt (1995) did not find any significant differences in IT productivity between "measurable" and "unmeasurable" sectors, indicating that appropriate quality measurement is mainly a problem at the aggregate level.
} 
Apart from these rather empirical arguments, there are also theoretical reasons why the firm-level might be the preferred reference for analysis. The productivity impact of ICT is likely to vary substantially between firms. Like in the case of many other innovation waves in economic history, some firms are better enabled than others to take productive advantage of new technologies. For the particular case of ICT, it has been argued that complementary factors like organizational restructuring, skill structure and intangible assets play a key role for ICT to unfold its largest benefits (Brynjolfsson and Hitt, 2000a; Yang and Brynjolfsson, 2001). The understanding of the underlying firm-level determinants of a productive use of ICT is crucial for the design of suited policies which aim at fostering productivity and growth. In industry- of country-level data, these firm-specific differences disappear in the process of aggregation. Therefore, in order to assess the determinants of successful ICT use, it seems appropriate to explicitly model the influence of various firm characteristics on the efficient use of new technologies in future research.

\section{The Data}

In order to implement the production framework empirically, data from the Mannheimer Innovation Panel in Services (MIP-S) are employed. This survey is conducted by the Centre for European Economic Research (ZEW) on behalf of the German Federal Ministry for Education and Research $(\mathrm{bmb}+\mathrm{f})$. The data has been collected annually since 1994 in a representative survey of innovation activities in the German business-related service and distribution sector and includes information from more than 2000 firms (Janz et al. 2001). It has an (unbalanced) panel structure in important key variables for the years since 1994. The survey methodology is closely related to the guidelines proposed in the Oslo-Manual on innovation statistics (OECD/Eurostat, 1997). Furthermore, the 1997 wave of the survey in the service sector is part of the Community Innovation Survey (CIS).

The MIP-S data set seems particularly appropriate to illustrate some of the effects of using different estimation strategies on the results concerning ICT productivity. Among many other features, the data set contains annual data on sales, number of employees (full-time equivalents), skill structures, expenditures for gross investment and for ICT-capital (including hardware, software and telecommunication technology) ${ }^{12}$ Similar information has been collected in many other existing data sets, too. In this section, some proceedings are suggested of how information from other external sources may be used to suitably transform the raw data from the survey to variables that are applicable to panel-data methods for the underlying production function framework.

As far as output $Y_{i t}$ is concerned the firms' value added would certainly be the most preferred measure. ${ }^{13}$ However, the data set does not contain information on intermediate goods and the given

\footnotetext{
${ }^{12}$ In fact, the analysis based on the MIP-S data set can be extended easily in future research making use of a variety of additional information such as innovation, R\&D, training, cooperation.

${ }^{13}$ Alternatively, intermediate goods should enter as an explanatory variable in the production function with sales as a measure of output.
} 
information on sales are an unsatisfactory proxy. However, the share of value added in sales will vary substantially across industries since industries that are typically at the end of the value chain (like wholesale and trade) are particularly dependent on intermediate goods in quantitative terms. In order to control for these differences and to deflate the corresponding output values, aggregate data from the German statistical office are employed to calculate the share of real value added in nominal gross output by industry at the two-digit NACE level. ${ }^{14}$ The firm-level data on sales are then multiplied by the corresponding industry-specific share of value added in sales. For labour input, the annual average of the number of employees in full-time equivalences as reported by the responding firms is used.

An important issue for assessing the productivity effects of ICT concerns the separate construction of capital stocks for ICT capital and conventional (non-ICT) capital from investment data. For this purpose, investment on conventional capital is defined as total investment expenditures minus ICT expenditures as reported by the firms. ${ }^{15}$ In order to derive the corresponding real investment, conventional investment is deflated by the deflator of the German Statistical office. 16 As far as deflators for ICT goods are concerned, however, German official price statistics on ICT goods tend to understate the real price decline of this product class (Hoffmann, 1998). Therefore, the ICT price index for Germany calculated by Schreyer (2000) is applied, who takes the obvious bias of official price indexes into account by calculating a harmonized price index for various OECD countries. He employs official statistics on ICT prices in the U.S., which are based on hedonic techniques, as a reference and assumes that the differences between price changes for ICT and non-ICT capital goods are the same across countries.

Given the deflated investments for both types of capital, the perpetual inventory method with constant, geometric depreciation, ${ }^{17}$ is applied to construct the capital stocks for ICT and non-ICT. Accordingly, the capital stock $K_{k t}$ of type $k$ in period $t$ results from investment $I_{t-1}$ in the following way:

$$
K_{k t}=\left(1-\delta_{k}\right) K_{k, t-1}+I_{k, t-1}
$$

\footnotetext{
${ }^{14}$ For this purpose, the time series 7711 and 7716 from the German Statistical Office are used.

${ }^{15}$ Some firms reported investment expenditures in ICT that exceeded total investment (leading to a negative gross investment in conventional capital). These inconsistencies were most frequent for the years 1994, 1997 and 1998 (6.3\%) but almost absent in 1995 and 1996 (0.2\%). The most likely explanation seems to be the questionnaire design: for the years 1995 and 1996, the question on total investment was immediately followed by the question on ICT investment, thereby drawing the respondent's attention to the consistency. To guarantee the quality of the data, firms with inconsistent information are dropped from the data set.

${ }^{16}$ The index of the producer prices for investment goods from the German Statistical Office was employed for this purpose.

${ }^{17}$ It may be argued that especially for the case of ICT capital it might be more adequate to apply a vintage model in which computers maintain their productive efficiency over the lifetime of computers (see for example Jorgenson and Stiroh, 1995). However, the definition of ICT includes a very broad range of technologies. Furthermore, the length of the time series available is very short. The average life cycle of ICT capital would exceed the time series available for the majority of the firms. Therefore, there is little gain in trying to exploit the potential advantages of the vintage approach in this context.
} 
with $k=1$ for conventional and $k=2$ for ICT capital and investment.

There are two issues in this approach to be addressed. First, reasonable values for the depreciation rates of both types of capital have to be defined. Secondly, since no information is available on the level of capital stocks, initial capital stocks have to be constructed for all individual firms. Therefore, the method proposed by Hall and Mairesse (1995) is applied!18 Under the assumption that investment expenditures in capital good $k$ have grown at a similar, constant average rate $g_{k}$ in the past for all firms, by backward substitution equation (10) can be rewritten for period $t=1$ (1994) in the following way: $\underline{19}$

$$
\begin{aligned}
K_{k 1} & =I_{k 0}+\left(1-\delta_{k}\right) I_{k,-1}+\left(1-\delta_{k}\right)^{2} I_{k,-2}+\ldots \\
& =\sum_{s=0}^{\infty} I_{k,-s}\left(1-\delta_{k}\right)^{s}=I_{k 0} \sum_{s=0}^{\infty}\left[\frac{1-\delta_{k}}{1+g_{k}}\right]^{s} \\
& =\frac{I_{k 1}}{g_{k}+\delta_{k}}
\end{aligned}
$$

Constant linear depreciation rates are assumed for conventional capital $\left(\delta_{1}\right)$ and ICT capital $\left(\delta_{2}\right)$ correspondingly. For $\delta_{1}$, the average depreciation rates by industries at the NACE two-digit level over the years 1991-1999 are employed.20 For ICT capital, a depreciation rate of 30\% is assumed. ${ }^{21}$ In particular, with $\delta_{1}<\delta_{2}$ it is taken into account that the fast technological progress in ICT implies more frequent replacement of ICT inventory than of conventional capital (including buildings and office furniture among others). In order to derive the initial capital stocks, assumptions about pre-period growth rates of both type of investments must be made. For non-ICT investment expenditures, an annual growth rate of approximately $5 \%\left(g_{1}=0.05\right)$ is assumed.22 For ICT investment, no time series are available for Germany. In order to get a rough idea of the evolution of

\footnotetext{
${ }^{18}$ Hall and Mairesse (1995) refer to the construction of an R\&D stock for which the problems are very similar.

${ }^{19}$ In fact, the initial value of investment in conventional capital $I_{1,1}$ is replaced by the average of the observed values of conventional investment for each firm. With this "smoothing" it is aimed to correct for cyclical effects which might have affected the estimated capital stock due to different initial years in the unbalanced panel. The underlying assumption is that long term growth of investment in conventional capital $\left(g_{1}=0.05\right)$ is relatively low compared to cyclical variations in this variable. On the contrary, the first observation on ICT capital is not replaced by the corresponding averages since long-term growth $\left(g_{2}=0.4\right)$ rates of ICT investment are more likely to dominate changes that are due to cyclical fluctuations.

${ }^{20}$ The depreciation rates by industries are calculated as the shares of capital consumption in net fixed assets evaluated at replacement prices as given by the time series 7719 and 7735 of the German Statistical Office. The resulting depreciation rates hardly vary over time such that averaging over time is of minor importance. The unweighed mean over all service industries amounts to $9 \%$ with a maximum in the NACE 72 (data processing) of $21 \%$ and a minimum in NACE 70 (real estate) with $2.2 \%$.

${ }^{21}$ Relying on available data from the U.S. indicated by Fraumeni (1997) and Moulton, Parker and Seskin (1999), depreciation rates for IT-hardware, software and telecommunication capital are assumed to be $31.2 \%$ for IT-hardware, $55.0 \%$ for prepackaged software, $33.0 \%$ for custom and own-account software and $15.0 \%$ for telecommunication capital. Using data by EITO (2001) for the year 1999, total ICT investment expenditures in Germany consist of $47.0 \%$ for IT-hardware, $26.9 \%$ for software and $26.1 \%$ for end-user and network telecommunication equipment. The weighted mean of depreciation rates — with the market shares as weights - yields an average depreciation rate of ICT capital of $\delta_{1}=0.312 \cdot 0.47+(0.55+0.33) / 2 \cdot 0.269+0.15 \cdot 0.261=0.304$.

${ }^{22}$ Calculations on capital data provided by Müller (1998) show that gross capital stock in German services has grown on average by $4.8 \%$ annually between 1980 and 1991 .
} 
ICT investments during the last decades, U.S. data are referred to as a rough guideline. Jorgenson and Stiroh (1995) calculate an average annual growth rate of $44.3 \%$ in real computer investment and of 20.2\% for OCAM (office, computing, and accounting machinery) between 1958 and 1992 for the U.S. Since the share of computers in OCAM has been rising continuously - reaching $94 \%$ in 1992 - , an annual pre-period growth rate close to the growth rate of computer investment of $g_{2}=0.4$ is assumed for ICT investment. ${ }^{23}$ Since there are time lags between the installation and the productive contribution of capital goods, the capital stock at each period's beginning (or at the end of the corresponding previous period) are taken as measures for ICT and conventional capital input.

In order to apply appropriate econometric techniques, only firms with consistent information on at least three consequent periods available are included in the sample. The resulting unbalanced reference sample (denoted "full sample") consists of 1177 firms with a total of 4939 observations. This corresponds to an average of 4.2 observed periods per firm. The statistics of the sample are summarized in Table 5 in the Appendix. The majority of firms in the reference sample are small and medium size firms with a median of 42 employees. About $10 \%$ of the sample consists of large firms with more than 500 employees, including some firms with several tens of thousands employees. This leads to a mean number of employees of 615 . Tables 8 and 9 show that the sample reflects industry and size structure of the German business-related and distribution services fairly well. ${ }^{24}$ Finally, the last two columns of Table 5, the (cross-sectional) means and medians of the firms' (longitudinal) averages of capital and output intensity (measured in capital per employee) are displayed for the firms in the sample. The figures indicate that in the median firm of the sample, a workplace is equipped with ICT capital worth Euro 1,397, and with non-ICT capital worth about Euro 24,979. The median value added per employee is Euro 60,307. 25

Even though transformed into full-time equivalences, the number of employees may be an imperfect measure of effective labour input. In particular, differences in the skill structure may vary substantially. For some firms, data on human capital - based on formal education - are available. Two particular variables are used to proxy human capital: the fraction of employees with vocational training (Berufs- or Fachschulabschluss) on the one hand, and the fraction of employees with a university degree including universities of applied sciences (Hochschul- or Fachhochschulabschluss) on the other. However, there is a vast amount of item non-responses in these variables, leading to a substantial decrease (nearly 50\%) in the number of firms with sufficient observations for panel analysis. In the remainder, this sub-sample will be referred to as the "small sample". As indicated in Table 6, the structure of this sample substantially differs from the full sample. In particular, the average firm size (194 employees) is only about a third of the firm size in the full sample. Therefore,

\footnotetext{
${ }^{23}$ In fact, later results in the production function estimates turn out to be robust to variations in both $g$ and $d$.

${ }^{24}$ Retail trade is slightly undersampled whereas traffic and postal services as well as software and telecommunication are slightly oversampled. As far as firm size is concerned, large firms are oversampled in their mere number and undersampled in their respective share in sales (see Table 8 ).

${ }^{25}$ The corresponding mean values are substantially higher than the median since some firms - in particular of real estate - display very high values for both inputs and output per employee.
} 
estimates based on the small sample will be used just to explore the effects of including human capital variables into the regression specification.

Some firms reported a share of ICT investment in total investment expenditures equal to zero for all the periods surveyed. Since the econometric specification is in logs, these firms should be excluded from the full sample. However, it may seem more reasonable to assume that ICT investment in these firms is not zero, in fact, but rather very low and rounded to zero by the respondents. 26 Excluding these firms might lead to an overestimation of the real output contributions of ICT in the economy. In order to explore this potential bias, a third sample (denoted "extended sample" in the remainder) is constructed. The only difference compared to the reference sample is that the ICT stock per worker in firms that reported zero ICT investment was assumed to be equal to the corresponding industry minimum and the corresponding values were imputed. The corresponding statistics (see Table 7) indicate that the endowment of workplaces with ICT is slightly smaller and the endowment with conventional capital is slightly higher than in the full sample whereas the other statistics are hardly affected by the imputations.

Independently of the specific sample used, the summary statistics both in absolute value and in per capita terms indicate that the share of ICT capital in the total capital stock is very low. Comparing the medians of ICT per worker and conventional capital per worker for the full sample (Table 5), ICT endowment amounts to $5.1 \%$ in total endowment. 27 Similarly, aggregating firms' time-averages of both types of capital over all firms in the sample yields a share of aggregate ICT capital in total aggregate capital of 5\% (not reported in the tables). These values are slightly higher than the share of $3 \%$ calculated by Schreyer (2000) using aggregate data for Germany in 1996 (including the manufacturing sector), which seems quite consistent if one considers that the service sector is a particularly intensive user of ICT capital. As argued in Griliches (1994), the overall small shares of ICT input together with measurement errors may make it difficult to distinguish the output contributions of ICT from stochastic events and may make the identification of productivity effects of ICT resemble the search for the "needle in the haystack". Therefore, in the empirical application, controlling for measurement errors will be an important issue.

\section{Econometrics and Empirical Results}

In this section, several econometric issues are discussed that need to be adressed for estimating the production function equations (1) and (6) consistently. To keep things simple, the more parsimonous Cobb-Douglas framework of equation 1 is used as a basis to investigate various potential biases subsequently. The most suitable SYS-GMM estimator will then be applied to investigate the effects of including information about the skill structure as suggested by equation

\footnotetext{
${ }^{26}$ Note that the definition of ICT investment as asked in the questionnaire is very broad, including expenditures for IT hardware, software and telecommunication equipment.

${ }^{27}$ Taking the corresponding means, the share is even lower $(1.8 \%)$.
} 
(2) and the extension to the translog specification of equation (6). In order to control for regional differences, all regressions include a dummy variable for firms located in East Germany. This variable is expected to be significantly negative since the transformation process in the Eastern part of Germany has been lagging behind in both productivity and wages when compared to West Germany.

To illustrate the effects of various biases, the Cobb-Douglas equation (1) with two types of capital is estimated firstly in a simple pooled OLS regression ${ }^{28}$ (see first column of Table 1). All regressions were computed using the DPD98 programme developed by Arellano and Bond (1998) running in GAUSS. For all results, heteroscedasticity-consistent standard errors are reported. The specification includes a constant and 6 time dummies (for the years $t=1994 \ldots 99$ ) interacted with 7 industries $(j=1 \ldots 7) .29$ This interaction will control for productivity variations induced by industry-specific business cycles, ${ }^{30}$ differences in price movements and in business cycles between industries cannot be captured by this specification. In the discussion of the SYS-GMM specification, the empirical relevance of including interacted dummies will be considered separately. 31

The coefficients of all three inputs from the pooled OLS regression in column 1 of Table 1 are significantly different from zero at the one percent level. The output elasticity of labour amounts to $60.7 \%$. ${ }^{32}$ What is most striking, however, is that the point estimate of the coefficient of ICT capital (24.4\%) exceeds the coefficient of conventional capital (14.9\%).

Similarly high ICT elasticities have been found in cross section regressions by Bertschek and Kaiser (2001) for a sample of firms in the business-related service sector. Applying a switching

\footnotetext{
${ }^{28}$ Note that from the econometric point of view, a pooled regression corresponds to a simple cross-section regression except that a larger number of observations can be obtained from the inclusion of several years.

${ }^{29}$ These are (with the corresponding NACE codes in brackets): wholesale trade (51), retail trade $(50,52)$, transport and postal services (60-63, 64.1), electronic data processing and telecommunications $(72,64.2)$, consultancies (74.1, $74.4)$, technical services $(73,74.2,74.3)$, and other business-related services $(70,71,745-748$, 90). Since there is no output data available for banking and insurance (only the balance sheet total and insurance premiums respectively), these industries are excluded from the analysis.

${ }^{30}$ Industry-specific demand shifts will lead to variations in the degree of factor utilization, which will translate into variations in factor productivity. If these demand shifts are particularly high (low) in industries with a more intensive use of ICT, this may lead to an overestimation (underestimation) of the productivity impacts of ICT. Moreover, even if there is no systematic link between ICT intensity and business cycles, variations in factor utilization may add substantial 'noise' to the residual variation in output. As already pointed out in section 3, the small share of ICT may make it difficult to distinguish the output contributions of ICT from stochastic events. Thus, including industry-specific cyclical effects reduces the stochastic noise and helps identify the contributions of ICT econometrically. However, the costs of including interacted time and industry dummies are substantial as well. There are $J \cdot T-1=7 \cdot 6-1=41$ additional variables that must be included, with $J$ representing the number of industries and $T$ the number of years.

${ }^{31}$ In a related study using firm-level panel data, Lichtenberg (1995) included not-interacted time and industry dummies in his regressions. Since he used undeflated sales as a measure of output, the industry dummies were supposed to control for differences in the share of value added in sales between industries and the time dummies were to capture overall price movements. In the analysis here, both these issues have been addressed by using industry data on shares of value added in gross output and price deflators. However, if undeflated sales were used, interaction of the dummies would be more flexible than in Lichtenberg (1995) by additionally allowing price changes to vary between industries.

${ }^{32}$ Under the assumption of constant returns to scale and perfect competition, the income share of labour in an economy must equal its labour coefficient in the production function. For the German economy as a whole, the average share of labour payments in national income between 1994 and 1999 amounted to 72.4\% (Statistisches Bundesamt, 2001).
} 
regression model to a cross-section of German services firms, they find elasticities of ICT varying between 0.156 and 0.197 and of non-ICT capital between 0.129 and 0.191 . Their underlying concept of ICT investments is similarly broad as in this study. Licht and Moch (1999) even report elasticities of PCs which are nearly twice as large as the elasticity of non-ICT capital for a cross-section of German manufacturing and service firms. By contrast, Brynjolfsson and Hitt (1995) report point estimates of the coefficients of ICT capital (10.9\%) that were only about half of the value for non-ICT capital $(20.9 \%)$ in a pooled regression for a sample drawn from the Fortune 500 Manufacturing and Service listings.

The high elasticities of ICT capital generally found in simple pooled (or cross section) regressions raise serious doubts about the correctness of the applied estimation specification. In the sample employed in this study, the average share of ICT capital in value added for the sample amounts to $6.2 \%$. If the elasticities had been estimated appropriately, this would imply rates of return to ICT investment of nearly $400 \% .33$ For conventional capital with an average share in value added of $258 \%$, the results imply rates of return of only $5.8 \%$. This difference can hardly be explained by higher user costs of ICT capital or returns to complementary investments that may be 'hidden' behind ICT investment (such as training of the workforce and innovation efforts). Rather, a more reasonable explanation is that the results from both pooled and simple cross-section regressions are biased. There are five potential sources that will be considered step by step in the following empirical exploration: unobserved heterogeneity between firms, simultaneity of the decisions about inputs and output, measurement errors in the input variables, omitted variables, and business cycles.

An important cause of the high elasticities of ICT found in the pooled regression may be unobserved firm characteristics. These firm effects may bias the results if the investment strategies of highly productive firms are systematically different from their less productive competitors within the same industry. ${ }^{34}$ It is very likely that highly productive firms with a skilled and flexible management will tend to invest more in new technologies than firms with low productivity do. In this case, the ICT coefficient will be biased upwards in a pooled or cross-section OLS regression. This hypothesis is supported by evidence in Brynjolfsson and Hitt (1995) who find that unobserved heterogeneity may explain as much as half of the productivity effects attributed to ICT. In the regression results reported in Table 1 in this study, the highly significant autocorrelation in the errors of both first- and second--order ${ }^{35}$ in the pooled regression further supports this view.

In order to control for the firm-specific effects, column 2 of Table 1 reports the results of the estimation in first differences. ${ }^{36}$ The figures indicate that once unobserved heterogeneity is

\footnotetext{
${ }^{33}$ Note that the marginal returns to ICT (MPI) are the product of the output elasticity of ICT and the inverse ratio of ICT capital in output: $M P I_{i t}=\partial Y_{i t} / \partial I C T_{i t}=\gamma_{2} \cdot Y_{i t} / I C T_{i t}$. Therefore, $M P I_{i t}$ increases with the output elasticity $\gamma_{2}$, but decreases with the share of ICT capital in output $I C T_{i t} / Y_{i t}$.

${ }^{34}$ Productivity differences between different industries are captured by the industry dummies.

${ }^{35}$ See the last two rows $\operatorname{AR}(1)$ and $\operatorname{AR}(2)$ of Table 1 .

${ }^{36}$ This means that the firms' corresponding fixed effects are eliminated by explaining output growth by the growth rates of the inputs.
} 
Table 1: Results for the ICT-augmented production function

\begin{tabular}{|c|c|c|c|c|c|c|c|}
\hline & \multicolumn{7}{|c|}{ Dep. Variable: sales (logs) } \\
\hline \multirow{3}{*}{ inputs $(\operatorname{logs})$} & (1) & $(2)$ & (3) & (4) & (5) & (6) & (7) \\
\hline & OLS & OLS & GMM $[-1]$ & GMM $[-2]$ & SYS-GMM & SYS-GMM & SYS-GMM \\
\hline & pooled & 1st dif & 1st diff. & 1st diff. & reference & not interact. & extended \\
\hline \multirow[t]{2}{*}{ labour } & $0.607^{* * *}$ & $0.598^{* * *}$ & $0.555^{* * *}$ & $0.282^{*}$ & $0.699^{* * *}$ & $0.717^{* * *}$ & $0.686^{* * *}$ \\
\hline & $(0.020)$ & $(0.075)$ & $(0.087)$ & $(0.154)$ & $(0.056)$ & $(0.056)$ & $(0.058)$ \\
\hline \multirow{2}{*}{ ICT capital } & $0.244^{* * *}$ & -0.025 & 0.024 & 0.032 & $0.060^{*}$ & 0.022 & $0.049^{*}$ \\
\hline & $(0.020)$ & $(0.017)$ & $(0.026)$ & $(0.041)$ & $(0.034)$ & $(0.034)$ & $(0.026)$ \\
\hline \multirow[t]{2}{*}{ non-ICT capital } & $0.149 * * *$ & -0.035 & 0.140 & $0.310^{* *}$ & $0.201^{* * *}$ & $0.213^{* * *}$ & $0.189^{* * *}$ \\
\hline & $(0.015)$ & $(0.052)$ & $(0.119)$ & $(0.157)$ & $(0.036)$ & $(0.037)$ & $(0.036)$ \\
\hline \multirow[t]{2}{*}{ East-Germany } & $-0.127 * * *$ & - & - & - & $-0.386^{* * *}$ & $-0.402^{* * *}$ & $-0.384^{* * *}$ \\
\hline & $(0.043)$ & & & & $(0.045)$ & $(0.047)$ & $(0.045)$ \\
\hline \multirow{2}{*}{$\begin{array}{l}\text { observations } \\
\text { firms }\end{array}$} & 4939 & 3762 & 3762 & 3762 & 4939 & 4939 & 5107 \\
\hline & 1177 & 1177 & 1177 & 1177 & 1177 & 1177 & 1222 \\
\hline $\mathrm{R}$-square & 0.844 & 0.236 & 0.218 & 0.137 & 0.843 & 0.839 & 0.836 \\
\hline \multirow{2}{*}{$\begin{array}{l}\text { Wald stat. [df]: } \\
\text { inputs } \\
\text { time and ind. } \\
\text { dummies }\end{array}$} & $24160[4]$ & $65.1[3]$ & $52.2[3]$ & $17.3[3]$ & $560[4]$ & $561[4]$ & $609[4]$ \\
\hline & $702[41]$ & $133[35]$ & $149[35]$ & $113[35]$ & $651[41]$ & $550[41]$ & $685[41]$ \\
\hline $\begin{array}{l}\text { Sargan ( } \mathrm{p} \text {-values) } \\
\text { errors ( } \mathrm{p} \text {-values): }\end{array}$ & - & - & 0.187 & 0.248 & 0.258 & 0.119 & 0.193 \\
\hline $\operatorname{AR}(1)$ & 0.000 & 0.005 & 0.007 & 0.006 & 0.004 & 0.004 & 0.003 \\
\hline $\operatorname{AR}(2)$ & 0.000 & 0.131 & 0.135 & 0.085 & 0.049 & 0.042 & 0.039 \\
\hline
\end{tabular}

$* * *, * *, *=$ significant on the 1,5 and 10 per cent level

All regressions contain a constant and industry interacted dummy variables for 6 years (1994-99) and 7 industries (no interaction only in regression 6). GMM[-1] and GMM[-2] refer to estimations using all lagged levels of explanatory variables with lag $\leq-1$ and -2 correspondingly (see text for details). For all regressions, heteroscedasticity consistent standard errors reported.

controlled for, the output contributions of both types of capital are no longer significantly different from zero whereas the labour coefficient remains virtually unchanged. ${ }^{37}$ The figures suggest that all the output contributions assigned to both types of capital in the pooled regression were in fact due to unobserved heterogeneity. These results coincide with very similar findings by Black and Lynch (2001) and Wolf and Zwick (2002) for production function estimates with one type of capital only. A further interesting feature of the results from the estimation in first differences is that the autocorrelation in the disturbance terms found in the pooled specification has vanished. Note that due to the first-differences specification, the observed highly significant first-order correlation of the errors is induced by the data transformation. 38 Therefore, the relevant test for equations in first differences is whether the corresponding errors are $\operatorname{AR}(2)$ or not. As shown in Table 1, autocorrelation of the errors can be rejected as soon as unobserved heterogeneity is taken into account.

\footnotetext{
${ }^{37}$ Since there is no variation in the East dummy over time, this variable is excluded from the first-differences estimation.

${ }^{38} \mathrm{It}$ is easy to see that if the errors $\epsilon_{i t}$ are i.i.d. with variance $\sigma^{2}$ their corresponding first differences will be $\mathrm{AR}(1)$ : $E\left(\Delta \epsilon_{i t} \cdot \Delta \epsilon_{i, t-1}\right)=E\left(\left(\epsilon_{i t}-\epsilon_{i, t-1}\right)\left(\epsilon_{i, t-1}-\epsilon_{i, t-2}\right)\right)=-\sigma^{2}$.
} 
The implausibly low estimates of the capital coefficients for the estimates in first differences may be due to a second type of bias due to measurement errors, as argued by Griliches and Hausman (1986). Measurement errors are likely to be substantial in both types of capital stocks. First, since there is no information available about the share of expansion investment in total investment expenditures, common depreciation rates for firms within the same industry are assumed. This may induce a substantial (though presumably not systematic) measurement error into the employed capital stocks. Second, in order to calculate approximate values for the initial levels of capital stocks, both the depreciation and the pre-sample growth rates are assumed equal across firms. Again, deviations from this assumption will add noise to the constructed capital stocks. By contrast, the measurement errors for labour input will be less severe, even though differences in skills and the transformation of part-time workers into full-time equivalents may - apart from the well-known problem of overtime accounting — add some measurement error here as well.

However, the downward bias due to measurement error may be offset by a second type of bias. If firms determine input and output simultaneously, exogenous shocks — like demand shifts, for example - result in an increase of both input and output ${ }^{39}$ In econometric terms, the disturbance term $\epsilon_{i t}$ will be positively correlated with the input variables in equation (5). Thus, the output elasticities of the corresponding factors will be biased upwards. The simultaneity bias may apply in particular to those factors that can be adjusted rapidly. This is not so much the case for capital stocks, however. Moreover, in the construction of the data, capital stocks at the beginning of the corresponding years have been used. Therefore, the (upwards) simultaneity bias is expected to be negligible for the two capital coefficients.

In order to correct for these two potential distortions, the GMM estimation approach is applied for the production function in first differences. This approach takes advantage of the panel structure of the data by instrumenting contemporaneous inputs in differences by the corresponding values in the past. ${ }^{40}$ More specifically, in the specification of column 3 of Table 1, the corresponding (log) levels of the lagged inputs $x_{t-1}, x_{t-2}, x_{t-3}, \ldots, x_{0}$ are used to instrument the input in differences $\Delta x_{t}=x_{t}-x_{t-1}(\mathrm{GMM}[-1])$, with $x$ denoting the inputs $L, I C T$ and $K{ }^{41}$ In column 4 , the instruments $x_{t-1}$ are dropped to allow for simultaneity of capital stocks at the beginnng of each period $t$ and shocks arising in $t(\mathrm{GMM}[-2])$. The corresponding results from the two-step estimation ${ }^{42}$

\footnotetext{
${ }^{39}$ For a simple formal derivation of the sources of the simultaneity bias in the production function framework, see Griliches and Mairesse (1995).

${ }^{40}$ See Mairesse and Hall (1996).

${ }^{41}$ Including $x_{t-1}$ as an instrument is based on the assumption that by taking capital stocks at the beginning of each period it is ensured that the inputs are predetermined, i.e. uncorrelated with the idiosyncratic shock $\epsilon_{i t}$ of the same period since $E\left(x_{t-1} \Delta \epsilon_{t}\right)=0 \Leftrightarrow E\left(x_{t-1} \epsilon_{t}\right)-E\left(x_{t-1} \epsilon_{t-1}\right)=0$. The validity of this assumption can be tested (see footnote 43). In the remainder, however, this moment condition will be dropped to explicitly control for potential simultaneity of inputs and output.

${ }^{42}$ The one-step results are reported in Table 10 in the appendix. In the one-step estimation, some ex ante known matrix is used as a weighting matrix for the moment conditions. This yields consistent though not efficient results. In the DPD98 programme, H=DD' — with D being the 'first difference transforming' matrix — is used in the one step
} 
show that in both specifications, the point estimates for the capital coefficients increase whereas the labour elasticity decreases. This tendency is much more pronounced in the GMM[-2] specification where the coefficient of conventional capital rises to 0.310 and the labour coefficient drops to a (quite unrealistic) value of $0.285 . \sqrt{43}$ However, the capital coefficients remain insignificant from zero in both these specifications when the one-step results are considered (see Table 10 in the appendix). Summarizing the results, these findings indicate that the measurement error bias in the capital coefficients clearly exceeds the counteracting simultaneity bias.44 By contrast, for the case of labour input, the simultaneity bias exceeds the measurement-error bias as it was expected. For both specifications, the Sargan test does not reject the validity of the instruments employed in this specification. Finally, like in the specification in OLS first differences, no autocorrelation of the error term is detected.

A possible reason for the insignificant capital coefficients found in the GMM regressions is the small power of the instruments used. Since capital stocks within firms are highly persistent over time, the correlation of the first differences with the second lag in levels is close to zero. $\frac{45}{4}$ Blundell and Bond (1998b) show that this may induce substantial finite-sample biases of the GMM estimator in first differences. Based on a specific application to production function estimation, Blundell and Bond (1998a) argue that the weak instruments will bias the GMM estimates in first differences in the direction of the within group estimation - that is towards zero - in the case of the capital coefficients which are particularly persistent by construction. They suggest using the SYS-GMM estimator originally proposed by Arellano and Bover (1995). In this estimation strategy, both the equation in differences is instrumented by suitably lagged differences (like in the simple GMM-estimation) and the equation in levels is instrumented by suitably lagged differences additionally. These two specifications are then estimated simultaneously. The additional moment conditions required for the equation in levels are not very restrictive. As shown by Blundell and Bond (1998b), only weak assumptions about the initial distribution of the variables used are necessary. In particular, the joint stationarity of the dependent and the independent variables is a sufficient, yet not necessary condition for the validity of the moment conditions for the equation in levels. Moreover, since the moments used in the GMM approach are a strict subset of the instruments used in the SYS-GMM estimation, the incremental Sargan statistic can be employed to

estimation (see Arellano and Bond (1998) for details). The resulting variance-covariance matrix of the errors is then used as a weighting matrix in the two-step estimation. The reported results in the text refer to this more efficient estimation specification. However, as argued in Blundell and Bond (1998b) on the basis of Monte Carlo simulations, "[i]nference based on one-step GMM estimators appears to be much more reliable when either non-normality or heteroskedasticity is suspected" (142).

43 The results of the Sargan difference test suggest that the additional moments employed in the GMM[-1] compared to the GMM[-2] specification $\left(E\left(x_{t-1} \Delta \epsilon_{t}\right)=0\right)$ cannot be rejected $(\mathrm{p}=0.186)$.

${ }^{44}$ These findings coincide with similar results in Black and Lynch (2001) for estimates of the production function with one type of capital only.

${ }^{45}$ Formally, this can be illustrated by assuming $K_{t}$ being $\operatorname{AR}(1): K_{t}=\rho K_{t-1}+\epsilon_{t}$ with $\epsilon \sim i . i . d$. If $K_{t}$ is weakly autocorrelated $(|\rho| \ll 1$ and $\rho \neq 0)$, the past levels are correlated with the contemporaneous levels. For the first available instrument $K_{t-2}$, this is: $E\left(\Delta K_{t} \cdot K_{t-2}\right)=E\left(\left(K_{t}-K_{t-1}\right) \cdot K_{t-2}\right)=E\left(K_{t} \cdot K_{t-2}\right)-E\left(K_{t-1} \cdot K_{t-2}\right)=\rho^{2}-\rho$. However, if the evolution of $K_{t}$ resembles a random walk $(\rho \approx 1)$, the correlation between the variable in differences and its past values in levels will disappear $\left(\rho^{2}-\rho \approx 0\right)$ and the instruments will therefore turn out to be weak. 
test for the validity of the additional instruments. $\stackrel{46}{4}$

The corresponding results ("SYS-GMM reference") are based on adding the corresponding additional moment conditions to the GMM[-2] specification. As shown in column 5 of Table 1, all three factor inputs are significantly positive. The output elasticity of labour amounts to about $70 \%$ which is consistent with the share of income from labour in the aggregate statistics (see footnote 32). The coefficients of ICT and non-ICT capital amount to $6 \%$ and $20 \%$ respectively, which coincides with the income share from total capital goods of roughly one third. The ICT coefficient is highly significant $\left(p=0.014\right.$ in the one-step estimation) ${ }^{47}$ The null-hypothesis of constant returns to scale (CRS) cannot be rejected at the $1 \%$-level (not reported). $\stackrel{48}{ }$ A further very robust result is that East-German firms in services are significantly less productive than their West-German counterparts. The coefficient of the East-Dummy (-0.386) implies that the multifactor productivity in East-German firms is only about two-thirds of the West-German level. This finding coincides with aggregate statistics on productivity differentials in Germany. The corresponding Sargan-statistic $(p=0.258)$ does not reject the validity of the instruments at the usual levels. These robust results indicate that there are indeed output contributions of ICT in the German service sector. Moreover, the incremental Sargan test (44.3[12]) does not reject the validity of the additional instruments obtained from the equation in levels $(\mathrm{p}=0.299)$.

Since these results stem from the preferred specification in this study, a glance at the implied rates of return may be worthwhile. Given the calculated average share of ICT capital in output of $6.2 \%$ for the firms in the sample, the results imply that one Euro invested in ICT capital yields Euros 1.96 as a return. 99 This high value is very similar to the findings in various related studies. ${ }^{[50}$ Assuming user costs of ICT of around $42 \%$ similar to Jorgenson and Stiroh (1995), the remaining excess returns to ICT of $54 \%$ may be due to complementary investment like training of the workforce, innovation efforts or costs due to the re-structuring of organizational forms which are not accounted for as inputs in the given framework.

In order to further investigate the sources of potential biases in assessing the productivity effects of ICT, the effect of ignoring different business cycles and inflation rates between industries is analyzed. To illustrate the importance of including interacted time and industry dummies, the SYS-GMM approach is estimated with simple (not-interacted) time and industry dummies. The corresponding results reported in column 5 ("SYS-GMM [2]") of Table 1 show that the coefficient of ICT capital is substantially affected by this change in the estimation specification. The corresponding point estimate reduces to roughly $2.2 \%$. As the statistics from the one-step estimates reveal, the coefficient is only marginally significant $(\mathrm{p}=0.099)$. In contrast, the coefficients

\footnotetext{
${ }^{46}$ See Arellano and Bond (1991) on details of this test.

${ }^{47}$ The less reliable $\mathrm{p}-$ value in the two-step estimation amounts to 0.078 .

${ }^{48}$ This result holds for both the one-step and the two-step estimation results.

${ }^{49}$ For non-ICT capital, the results imply that one Euro invested yields a much smaller return of Euro 1.078.

${ }^{50}$ See Brynjolfsson and Hitt (2000a).
} 
of the other explanatory variables do not exhibit any remarkable changes as compared to the specification with interacted dummies. ${ }^{[1]}$ These results suggest that it is important to control for industry-specific business cycles by including interacted industry and time dummies in order to assess the contributions of ICT correctly.

In the last column of Table 1 (SYS-GMM [3]), results for the SYS-GMM estimation with interacted dummies are replicated for the extended sample, in which also those firms are included that reported zero ICT investment for all the periods surveyed. The corresponding results are based on the same estimation method as column 5 (SYS-GMM). As explained in more detail in section 3, this sample is extended by 46 firms that have reported zero ICT investment for all years observed. For these firms, the industry minimum in terms of ICT per worker is assumed to be a more reasonable approximation. The inclusion of these firms slightly lowers the point estimate for ICT $(4.9 \%)$ as compared to the values reported for the reference sample. Moreover, the ICT coefficient is significantly positive only in the two-step estimation. ${ }^{52}$ These results appear very reasonable if one considers that firms may differ in their output elasticities. Those firms with a lower output elasticity of ICT will be maximizing profits with a lower share of ICT capital in output; excluding these firms might therefore overstate the ICT coefficient. ${ }^{53}$

Finally, an important issue of estimating the productivity effects of ICT in the production function framework is the potential bias owing to omitted variables that are potentially complementary to the firm's use of ICT. In particular, recent studies find that human capital plays an important role in this regard (Bresnahan, Brynjolfsson and Hitt, 2002). Furthermore, Brynjolfsson and Yang (1999) argue that the use of ICT is strongly complementary to intangible assets. On the one hand, ignoring these complementary factors might lead to an overestimation of the true impacts of ICT on production if the output contributions of these factors are wrongly assigned to the mere use of ICT. On the other hand, a firm's human capital and intangible assets are likely to be quite persistent. If these complementary assets hardly vary over time, their effect will not be distinguishable from other factors like management skills etc. which are controlled for as unobserved heterogeneity between firms. In this case, no distortions are to be expected from the omission of these variables in the estimation equation.

In order to assess the potential biases from omitting the probably most important source, human capital, the list of independent variables is extended by the shares of employees with vocational training and with university degree or equivalent correspondingly. As discussed in section 3, the resulting 'small sample' consists of only 591 firms, which is half of the full sample. The results of the corresponding regression are surveyed in Table 11. The first column applies the SYS-GMM reference estimation strategy (column 5 in Table 1) to the small sample. The most striking result is

\footnotetext{
${ }^{51}$ Again, the Sargan statistic does not reject the validity of the instruments $(p=0.119)$.

${ }^{52}$ The one-step estimates imply a p-value for the ICT coefficient of 0.107 .

${ }^{53}$ The Sargan statistic of the extended sample does not reject the validity of the instruments $(p=0.193)$.
} 
Table 2: The effects of including human capital

\begin{tabular}{lcc}
\hline & \multicolumn{2}{c}{ Dep. Variable: sales (logs) } \\
\hline inputs (logs) & small & small w. skill \\
\hline \hline labour & $0.737^{* * *}$ & $0.656^{* * *}$ \\
& $(0.122)$ & $(0.063)$ \\
ICT capital & 0.015 & 0.017 \\
& $(0.050)$ & $(0.040)$ \\
non-ICT capital & $0.168^{* *}$ & $0.208^{* * *}$ \\
& $(0.077)$ & $(0.051)$ \\
East-Germany & $-0.327^{* * *}$ & $-0.416^{* * *}$ \\
& $(0.074)$ & $(0.066)$ \\
\% university & - & $0.827^{* * *}$ \\
& & $(0.194)$ \\
\%vocational & - & $0.475^{* * *}$ \\
& & $(0.120)$ \\
\hline observations & 1887 & 1887 \\
number of firms & 591 & 591 \\
R-square & 0.825 & 0.836 \\
Wald statistics[df] & & \\
inputs & $224[4]$ & $497[6]$ \\
time and ind. dummies & $393[34]$ & $449[34]$ \\
Sargan (p-values) & 0.591 & 0.198 \\
errors (p-values): & & \\
AR(1) & 0.024 & 0.029 \\
AR(2) & 0.146 & 0.163 \\
\hline
\end{tabular}

$* * *,{ }^{* *}, *=$ significant at the 1,5 and 10 per cent level

All regressions are based on SYS-GMM and contain a constant and industry dummy variables interacted with year dummy variables. Heteroscedasticity consistent standard errors reported.

that the coefficient of labour (0.737) is slightly higher for the small sample, both capital coefficients are substantially smaller. 54 The main reason for the differing results seems to be that average firm size is much smaller in the small sample.55 Moreover, the average and median endowment of workplaces with ICT capital is substantially lower in the small sample. ${ }^{[5]}$ By contrast, the industry composition in both samples is very similar and reflects the population fairly well (see Table 8). The reduction in the significance levels of both the capital coefficients may be a direct consequence of the loss of information due to the much smaller sample size.

The effect of including the proxies for human capital in the regression becomes obvious from the results displayed in the second column of Table 11. Both the share of employees with university degree and the share of workers with vocational training are highly significant and positive ${ }^{57}$ with the university share having a much higher impact by size of the coefficient as is to be expected ${ }^{58}$ As

\footnotetext{
${ }^{54}$ Moreover, neither coefficient is significantly different from zero in the one-step estimation.

${ }^{55}$ See Tables $[5]$ and 6 as well as section 3 .

${ }^{56}$ See last columns of Tables $\underline{5}$ and $\underline{6}$.

${ }^{57}$ This holds for both the one-step and two-step results.

${ }^{58}$ The implicit values for the productivity differentials for medium- and high-skilled workers are $\theta_{m}=\beta_{m} / \gamma_{1}=$
} 
the comparison to the first column reveals, including the human capital variables slightly reduces the coefficients of labour and increases the coefficient of non-ICT capital. Most importantly, however, the elasticity of ICT remains virtually unaffected at 0.017. This suggests that omitting the skill levels does not affect the corresponding results concerning ICT productivity but will rather be captured as a firm-specific effect by the SYS-GMM estimator. ${ }^{59}$

A final issue to be discussed is the functional form of the production technology. As briefly discussed, the Cobb-Douglas technology of equation (1) may be too restrictive. In order to assess this question, both the simplest (pooled OLS) and the most complex (SYS-GMM) estimations are replicated based on the translog production function of equation (6). The corresponding results and the average elasticities calculated from equation (7) are reported in the first two columns of Tables (3) and (4). Like in the estimations for the Cobb-Douglas framework, substantial differences are found between OLS and SYS-GMM estimates in both the individual coefficients and the implicit average elasticities. In particular, the output contributions are substantially overestimated by using pooled OLS. A striking feature for the translog function is that even for the SYS-GMM estimation, the implicit average elasticity of ICT (0.148) is much higher than in the Cobb-Douglas specification.60 This suggests that either the Cobb-Douglas is too restrictive or that the translog specification yields misleading results.

There are two features of the results that raise doubts about the reliability of the translog results. First, the Wald statistic for the joint significance of the additional translog inputs ${ }^{61}$ from the one-step estimation rejects the relevance of these variables (4.96[6], $\mathrm{p}=0.549$ ). Second, the translog estimates prove to be highly sensitive to small changes in the sample. To illustrate this, the SYS-GMM estimator is applied to the extended sample instead of the full sample as in column 2. This extension of the sample by 45 firms (3.8\% of the sample) causes substantial changes in the ICT-related coefficients (see column 3 of Table 3). Moreover, the average elasticities for all three inputs change substantially (see Table 4). By contrast, the sensitivity to sample changes was much smaller for the Cobb-Douglas specification (see columns 5 and 7 of Table 1). The underlying reason may be that in particular the quadratic terms are very sensitive to potential outliers in the sample.

To sum up, the findings of these econometric explorations indicate that unobserved heterogeneity, measurement errors and industry-specific time effects may lead to substantial distortions

$0.475 / 0.656=0.724$ and $\theta_{h}=\beta_{h} / \gamma_{1}=1.26$. With competitive salaries in the labour market, these values should roughly correspond to the wage spread over the corresponding skill levels. For the service sector, Kaiser (2000) calculates that average wages for high-skilled workers exceed the average wages of unskilled workers by a factor of 2.025 (which is equivalent to $\theta_{h}=1.025$ ) and a factor of 1.325 for medium skilled workers $\left(\theta_{m}=0.325\right)$. This comparison shows that the rather inaccurate approximation in eq. 4 may lead to a slight overestimation of the corresponding coefficients.

${ }^{59}$ In a related exercise, Lehr and Lichtenberg (1999) report a similar qualitative result.

${ }^{60} \mathrm{In}$ a similar comparison between the Cobb-Douglas and the translog specification, Brynjolfsson and Hitt (1995) find an only slightly higher average elasticity of ICT for the translog version.

${ }^{61}$ These are the regressors $L^{2}, I C T^{2}, K^{2}, L \cdot I C T, L \cdot K, I C T \cdot K$ which are not included in the Cobb-Douglas specification. 
Table 3: Results for the translog production function

\begin{tabular}{|c|c|c|c|}
\hline inputs (log) & $\begin{array}{l}\text { OLS } \\
\text { full }\end{array}$ & $\begin{array}{l}\text { SYS-GMM } \\
\text { full }\end{array}$ & $\begin{array}{l}\text { SYS-GMM } \\
\text { extended }\end{array}$ \\
\hline labour & $\begin{array}{c}1.100^{* * *} \\
(0.104)\end{array}$ & $\begin{array}{c}1.178^{* * *} \\
(0.137)\end{array}$ & $\begin{array}{c}1.077^{* * *} \\
(0.144)\end{array}$ \\
\hline ICT capital & $\begin{array}{c}0.050 \\
(0.068)\end{array}$ & $\begin{array}{l}-0.045 \\
(0.085)\end{array}$ & $\begin{array}{c}0.006 \\
(0.070)\end{array}$ \\
\hline non-ICT capital & $\begin{array}{c}0.065 \\
(0.048)\end{array}$ & $\begin{array}{c}0.156^{* * *} \\
(0.055)\end{array}$ & $\begin{array}{c}0.169^{* * *} \\
(0.059)\end{array}$ \\
\hline labour $^{2}$ & $\begin{array}{c}-0.040^{* * * *} \\
(0.011)\end{array}$ & $\begin{array}{c}-0.049^{* * * *} \\
(0.013)\end{array}$ & $\begin{array}{c}-0.045^{* * *} \\
(0.015)\end{array}$ \\
\hline $\mathrm{ICT}_{\text {capital }}{ }^{2}$ & $\begin{array}{c}0.006 \\
(0.005)\end{array}$ & $\begin{array}{c}0.001 \\
(0.006)\end{array}$ & $\begin{array}{c}0.008^{* * *} \\
(0.003)\end{array}$ \\
\hline non-ICT capital ${ }^{2}$ & $\begin{array}{c}0.031^{* * *} \\
(0.005)\end{array}$ & $\begin{array}{l}0.013^{*} \\
(0.007)\end{array}$ & $\begin{array}{l}0.008 \\
(0.007)\end{array}$ \\
\hline labour*ICT & $\begin{array}{c}0.059^{* * *} \\
(0.012)\end{array}$ & $\begin{array}{c}0.049^{* * *} \\
(0.016)\end{array}$ & $\begin{array}{c}0.043^{* * *} \\
(0.013)\end{array}$ \\
\hline labour*non-ICT & $\begin{aligned}-0.020^{*} \\
(0.010)\end{aligned}$ & $\begin{array}{l}-0.008 \\
(0.012)\end{array}$ & $\begin{array}{l}-0.004 \\
0.0144\end{array}$ \\
\hline $\mathrm{ICT}^{*}$ non-ICT & $\begin{array}{c}-0.042^{* * *} \\
(0.008)\end{array}$ & $\begin{array}{l}-0.009 \\
(0.008)\end{array}$ & $\begin{array}{l}-0.009 \\
(0.007)\end{array}$ \\
\hline East-Germany & $\begin{array}{c}-0.336^{* * *} \\
(0.042)\end{array}$ & $\begin{array}{c}-0.607^{* * *} \\
(0.146)\end{array}$ & $\begin{array}{c}-0.544^{* * *} \\
(0.145)\end{array}$ \\
\hline observations & 4939 & 4939 & 5107 \\
\hline firms & 1177 & 1177 & 1222 \\
\hline $\mathrm{R}$-square & 0.859 & 0.850 & 0.846 \\
\hline $\begin{array}{l}\text { Wald-statistics[df]: } \\
\text { all inputs } \\
\text { additional inputs } \dagger \\
\text { time and ind. dummies }\end{array}$ & $\begin{array}{c}6,801[10] \\
77.15[6] \\
721.6[41] \\
\end{array}$ & $\begin{array}{l}7,479[10] \\
22.88[6] \\
767.1[41]\end{array}$ & $\begin{array}{c}6,556[10] \\
89.82[6] \\
804[41] \\
\end{array}$ \\
\hline $\begin{array}{l}\text { Sargan ( } \mathrm{p} \text {-values) } \\
\text { errors ( } \mathrm{p} \text {-values) }\end{array}$ & - & 0.144 & 0.080 \\
\hline $\operatorname{AR}(1)$ & 0.000 & 0.003 & 0.004 \\
\hline $\operatorname{AR}(2)$ & 0.000 & 0.043 & 0.047 \\
\hline
\end{tabular}

$* * *, * *, *=$ significant at the 1,5 and 10 per cent level

The results of the second column are based on the two-step SYS-GMM and contain a constant and industry dummy variables interacted with year dummy variables. Heteroscedasticity consistent standard errors reported.

trefers to additional inputs not included in Cobb-Douglas specification.

in assessing the productivity impacts of ICT. Most prominently, ignoring unobserved heterogeneity leads to an overestimation of these impacts whereas measurement errors and the omission of industry-specific cyclical effects work into the opposite direction. The potential upward bias from simultaneity issues is - at least compared to the measurement error bias - relatively low. When all these effects are controlled for in an adequate SYS-GMM estimation with interacted time and 
Table 4: Implicit average elasticities for the translog production function

\begin{tabular}{lccc}
\hline inputs & $\begin{array}{c}\text { OLS } \\
\text { full }\end{array}$ & $\begin{array}{c}\text { SYS-GMM } \\
\text { full }\end{array}$ & $\begin{array}{c}\text { SYS-GMM } \\
\text { extended }\end{array}$ \\
\hline labour & 0.707 & 0.677 & 0.619 \\
ICT capital & 0.215 & 0.148 & 0.124 \\
non-ICT capital & 0.140 & 0.168 & 0.193 \\
\hline
\end{tabular}

industry dummies (column 5 of Table 1), an ICT elasticity of about $6 \%$ is found implying a net rate of return to ICT of more than $50 \%$. These excess returns point to the importance of adjustment costs or (unobserved) complementary investments in intangible assets. Finally, further explorative analyzes show that the omission of human capital in the production function is not severe for the estimated ICT productivity when firm effects are taken into account. Finally, the more flexible translog production function yields higher ICT elasticities, but is not found to be robust with respect to changes in the sample.

\section{Conclusions}

The use of firm-level data is gaining increasing importance for the analysis of productivity effects of ICT and the underlying determinants. In contrast to aggregate data, firm-level information is much less dependent on the accuracy of the correct deflators provided by statistical offices and entails a higher variation in the factors that are supposed to determine the performance of businesses. Both aspects have helped to overcome the so called 'productivity paradox'.

In this paper, it is shown that the empirical results on the productivity of ICT gained from a production function framework are highly contingent upon the specific econometric methods applied. The empirical analysis based on firm-level panel data from a German innovation survey in services yields evidence of various interfering influences that require the application of appropriate quantitative techniques. First, well-managed firms are likely to be intensive users of ICT. If these unobservable firm effects are not taken into account by using a first-differences or a within-estimator, the productivity impacts of ICT will be drastically overstated. Second, counteracting this effect, measurement errors in the explanatory variables may lead to a substantial underestimation of the corresponding elasticities. This problem turns out to be particularly important for the case of ICT capital. Even though ICT investment has increased substantially over the last years, the share of ICT equipment and software in total capital is still very small. This makes it difficult to distinguish the output contributions of ICT from statistical noise. By contrast, third, the simultaneity of input and output decisions by firms, which may induce an upward bias of the output contributions of ICT, is found to be less important for the econometric specification. If panel data are available, both the measurement error bias and the simultaneity bias may be overcome by applying a GMM estimator 
that uses information from suitably distant previous periods to instrument the production inputs of the firm. However, when unobserved firm-effects are taken into account, too, this estimation strategy may suffer from small sample biases due to weak instruments. Therefore, the most convincing approach is found to be the system GMM (SYS-GMM) strategy proposed by Arellano and Bover (1995). This approach applies the GMM estimator to the firms' production function equation in levels and first differences simultaneously and makes use of more powerful instruments.

Fourth, it is found that the omission of industry-specific business cycles may lead to an underestimation of the productivity impacts of ICT also at the firm-level. This bias may be addressed by including interacted time and industry dummies in the regression. Fifth, the shares of high- and medium skilled workers are found to have large and significant effects on productivity. However, the omission of these variables does not lead to an overestimation of the productivity contributions of ICT as long as firm-specific fixed effects are taken into account. Obviously, most of the variation in the skill structure is between firms rather than within firms and can be captured by the fixed-effect correction. Finally, estimates based on the more flexible translog production function yield higher ICT elasticities than the Cobb-Douglas specification. However, the translog-estimates turn out to be much more sensitive with respect to small changes in the sample and yield little improvements in the explanatory power compared to the more parsimonious Cobb-Douglas specification.

What about the implications for the empirical work on the economics of ICT? On the one hand, the data needs that are necessary to address the methodological issues raised in this paper are indeed very demanding. In particular, a longitudinal structure of at least three observations per firm is required to apply the suited SYS-GMM estimator. On the other hand, the calibration strategies proposed in this paper for the construction of appropriate input and output data may be applicable to various other existing longitudinal microdata sets, which frequently contain information on sales, employment and investment. In any case, great caution seems to be appropriate for the interpretation of cross-section results on the topic. The findings of this study indicate that a big part of such results may be due to spurious correlations that tend to dominate the real causal impacts of ICT on the productivity of businesses.

As far as economics is concerned, the findings of this paper point to the need of investigating particular firm characteristics and strategies in more detail. The results from the preferred system GMM estimation imply that a one-percent increase in ICT raises output by about 0.06 percent. This corresponds to a net-rate of return to ICT investment of more than 50\%. These apparent excess returns are very likely to be due to unobserved complementary expenses such as adjustment cost, innovation efforts, training or intangible assets, but they may also reflect differences between firms in their ability to exploit the potential benefits of ICT. Therefore, the exploration of relevant firm characteristics and complementary efforts related to ICT use will be an important issue for future research on the productivity and welfare impacts of the 'New Economy'. 


\section{References}

Arellano, M. and Bond, S. (1991). Some Tests of Specification for Panel Data: Monte Carlo Evidence and an Application to Employment Equations, Review of Economic Studies 58: 277-297.

Arellano, M. and Bond, S. (1998). Dynamic Panel Data Estimation Using DPD98 for GAUSS: A Guide for Users. ftp://ftp.cemfi.es/pdf/papers/ma/dpd98.pdf.

Arellano, M. and Bover, O. (1995). Another Look at the Instrumental Variable Estimation of ErrorComponents Models, Journal of Econometrics 68: 29-51.

Bertschek, I. and Kaiser, U. (2001). Productivity Effects of Organizational Change: Microeconometric Evidence, ZEW Discussion Paper No. 01-32, Centre for European Economic Research $(\mathrm{ZEW})$.

Biscourp, P., Crepon, B., Heckel, T. and Riedinger, N. (2002). How Do Firms Respond To Cheaper Computers?, CREST-INSEE, mimeo.

Black, S. E. and Lynch, L. M. (2001). How to Compete: The Impact of Workplace Practices and Information Technology on Productivity, Review of Economics and Statistics 83: 435-445.

Blundell, R. and Bond, S. (1998a). GMM Estimation with Persistent Panel Data: an Application to Production Functions, Working Paper Series No. W99/4, Institute for Fiscal Studies.

Blundell, R. and Bond, S. (1998b). Initial Conditions and Moment Restrictions in Dynamic Panel Data Models, Journal of Econometrics 87: 115-143.

Bresnahan, T. F., Brynjolfsson, E. and Hitt, L. M. (2002). Information Technology, Workplace Organization, and the Demand for Skilled Labor: Firm-Level Evidence, Quarterly Journal of Economics 117: 339-376.

Brynjolfsson, E. (1994). Technology's true payoff, Informationweek, October 10 pp. 34-36.

Brynjolfsson, E. and Hitt, L. (1995). Information Technology as a Factor of Production: Thr Role of Differences among Firms, Economics of Innovation and New Technology 3: 183-199.

Brynjolfsson, E. and Hitt, L. (1996). Paradox Lost? Firm-level Evidence on the Returns to Information Systems Spending, Management Science 42/4: 541-558.

Brynjolfsson, E. and Hitt, L. M. (1998). Information Technology and Organizational Design, mimeo, MIT Sloan School of Management. http://ebusiness.mit.edu/erik/ITOD.pdf.

Brynjolfsson, E. and Hitt, L. M. (2000a). Beyond Computation: Information Technology, Organizational Transformation and Business Performance, Journal of Economic Perspectives 14: 23-48. 
Brynjolfsson, E. and Hitt, L. M. (2000b). Computing Productivity: Firm-Level Evidence, mimeo, University of Pennsylvania, Wharton School.

Brynjolfsson, E. and Yang, S. (1996). Information Technology and Productivity: A Review of the Literature, Advances in Computers 43: 179-214.

Brynjolfsson, E. and Yang, S. (1999). The Intangible Costs and Benefits of Computer Investments: Evidence from the Financial Markets, Proceedings of the International Conference on Information Systems, Atlanta, Georgia, MIT Sloan School.

Christensen, L. R. and Jorgenson, D. W. (1969). The Mesurement of U.S. Real Capital Input, 1929-1967, Review of Income and Wealth 15/4: 293-320.

Colecchia, A. and Schreyer, P. (2001). ICT Investment and Economic Growth in the 1990s: Is the United States a Unique Case?, STI Working Papers 2001/7, OECD.

EITO (2001). European Information Technology Observatory 2001, EITO, Frankfurt/Main.

Fraumeni, B. M. (1997). The Measurement of Depreciation in the U.S. National Income and Product Accounts, Survey Of Current Business 77/7: 7-23.

Greenan, N. and Mairesse, J. (1996). Computers and Productivity in France: Some Evidence, Working Paper No. 5836, National Bureau of Economic Research.

Greenan, N., Mairesse, J. and Topiol-Bensaid, A. (2001). Information Technology and Research and Development Impacts on Productivity and Skills: Looking for Correlations on French Firm Level Data, NBER Working Paper Series No. 8075, National Bureau of Economic Research.

Griliches, Z. (1994). Productivity, R\&D, and the Data Constraint, American Economic Review 84: $1-23$.

Griliches, Z. and Hausman, J. A. (1986). Errors in Variables in Panel Data, Journal of Econometrics 31: $93-118$.

Griliches, Z. and Mairesse, J. (1995). Production Functions: The Search for Identification, NBER Working Paper No. 506\%, National Bureau of Economic Research.

Hall, B. H. and Mairesse, J. (1995). Exploring the Relationship Between R\&D and Productivity in French Manufacturing Firms, Journal of Econometrics 65: 263-293.

Hoffmann, J. (1998). Problems of Inflation Measurement in Germany, Discussion Paper No. 01-98, Economic Research Centre of the Deutsche Bundesbank. 
Janz, N., Ebling, G., Gottschalk, S. and Niggemann, H. (2001). The Mannheim Innovation Panels (MIP and MIP-S) of the Centre for European Economic Research (ZEW), Schmollers Jahrbuch 121: $123-129$.

Jorgenson, D. W. and Stiroh, K. (1995). Computers and Growth, Economics of Innovation and New Technology 3: 295-316.

Kaiser, U. (2000). A Note on the Calculation of Firm-specific and Skill-specific Labor Costs from Firm-level Data, ZEW Discussion Paper 00-08, Centre for European Economic Research.

Lehr, B. and Lichtenberg, F. (1999). Information Technology and its Impact on Productivity: FirmLevel Evidence from Government and Private Data Sources, Canadian Journal of Economics 32(2): 335-362.

Licht, G. and Moch, D. (1999). Innovation and Information Technology in Services, Canadian Journal of Economics 32: 363-383.

Lichtenberg, F. R. (1995). The Output Contributions of Computer Equipment and Personnel: A Firm-Level Analysis, Economics of Innovation and New Technology 3: 201-217.

Mairesse, J. and Hall, B. H. (1996). Estimating the Productivity of Research and Development in French and United States Manufacturing Firms: An Exploration of Simultaneity Issues with GMM Methods, in K. Wagner and B. van Ark (eds), International Productivity Differences: Measurement and Explanations, Elsevier Science Publishers B.V., Amsterdam, pp. 285-315.

Moulton, B. R., Parker, R. P. and Seskin, E. P. (1999). A Preview of the 1999 Comprehensive Revision of the National Income and Product Accounts - Definitional and Classificational Changes, Survey of Current Business 79: 7-20.

Müller, A. A. (1998). Kapitalstock und Produktionspotential im privaten und öffentlichen Sektor Deutschlands, Nomos, Baden-Baden.

Schreyer, P. (2000). The Contribution of Information and Communication Technology to Output Growth: A Study of the G7 Countries, STI Working Paper 2000/2, OECD.

Statistisches Bundesamt (2001). Statistical Yearbook for the Federal Republic of Germany, MetzlerPoeschel, Stuttgart.

Stiroh, K. J. (2001). Information Technology and the U.S. Productivity Revival: What Do the Industry Data Say?, Staff Report No. 115, Federal Reserve Bank of New York.

Uchitelle, L. (2000). Economic view: Productivity finally shows the impacts of computers, New York Times p. 23. 12th of March, section 3. 
Wolf, E. and Zwick, T. (2002). Reassessing the Impact of High Performance Workplaces, $Z E W$ Discussion Paper 02-07, Centre of European Economic Research.

Yang, S. and Brynjolfsson, E. (2001). Intangible Assets and Growth Accounting: Evidence from Computer Investments, mimeo, New York University.

\section{Appendix}

Table 5: Detailed statistics for the full sample (4939 obs. for 1177 firms)

\begin{tabular}{lccccccccc}
\hline \hline & & & \multicolumn{4}{c}{ percentiles } & \multicolumn{3}{c}{ per employee } \\
& mean & std. & min. & max. & $10 \%$ & $50 \%$ & $90 \%$ & mean & median \\
\hline \hline value added* & 54.541 & 717.21 & 0.118 & 27,380 & 0.362 & 2.647 & 40.705 & 121,917 & 60,307 \\
employees $^{\text {ICT capital* }}$ & 614.563 & 9379 & 1 & 310,792 & 7 & 42 & 506 & - & - \\
non-ICT capital* & 5.058 & 131.25 & $<0.001$ & 6,537 & 0.006 & 0.488 & 0.923 & 3,946 & 1,392 \\
East (dummy) & 0.421 & 1833.645 & 0.001 & 60,340 & 0.061 & 1.107 & 56.360 & 218,492 & 24,979 \\
\hline
\end{tabular}

*measured in million Euro, except for values per employee

Table 6: Detailed statistics for the small sample (1887 obs. for 591 firms)

\begin{tabular}{lccccccccc}
\hline \hline & & & & \multicolumn{4}{c}{ percentiles } & \multicolumn{3}{c}{ per employee } \\
& mean & std. & min. & max. & $10 \%$ & $50 \%$ & $90 \%$ & mean & median \\
\hline \hline value added* & 18.965 & 88.136 & 0.032 & 1,124 & 0.362 & 2.308 & 26.414 & 119,624 & 58,778 \\
employees & 194.995 & 624.633 & 1 & 7,200 & 7 & 36 & 340 & - & - \\
ICT capital* $_{\text {non-ICT capital* }}^{*}$ & 0.384 & 1.522 & $<0.001$ & 30.855 & 0.006 & 0.041 & 0.574 & 3,107 & 1,257 \\
East (dummy) & 0.441 & 125.778 & 0.003 & 1,840 & 0.061 & 0.932 & 43.506 & 233,234 & 24,650 \\
\hline
\end{tabular}

*measured in million Euro, except for values per employee 
Table 7: Detailed statistics for the extended sample (5107 obs. for 1222 firms)

\begin{tabular}{lccccccccc}
\hline \hline & & & & \multicolumn{4}{c}{ percentiles } & \multicolumn{3}{c}{ per employee } \\
& mean & std. & min. & max. & $10 \%$ & $50 \%$ & $90 \%$ & mean & median \\
\hline \hline value added* $^{*}$ & 53.145 & 705.526 & 0.012 & 27,380 & 0.351 & 2.495 & 39.805 & 122,198 & 60,575 \\
employees & 596.7 & 9224 & 1 & 310,792 & 7 & 40 & 499 & - & - \\
ICT capital* & 4.892 & 129.075 & $<0.001$ & 6,537 & 0.004 & 0.045 & 0.892 & 3,801 & 1,302 \\
non-ICT capital* & 100.300 & 1,803 & 0.001 & 60,340 & 0.060 & 1.060 & 55.375 & 226,947 & 25,574 \\
East (dummy) & 0.422 & 0.494 & 0 & 1 & 0 & 0 & 1 & - & - \\
\hline
\end{tabular}

*measured in million Euro, except for values per employee

Table 8: Comparison of the different samples and the population by industries

\begin{tabular}{lccccccccc}
\hline & & \multicolumn{4}{c}{ samples } & \multicolumn{3}{c}{ population* } \\
& & \multicolumn{2}{c}{ full } & \multicolumn{2}{c}{ small } & \multicolumn{2}{c}{ extended } & \\
\hline industry & nace-digit & $\#$ & $\%$ & $\#$ & $\%$ & $\#$ & $\%$ & $\%$ \\
\hline wholesale trade & 51 & 163 & 13.9 & 86 & 14.6 & 172 & 14.1 & 10.6 \\
retail trade & 50,52 & 183 & 15.6 & 87 & 14.7 & 190 & 15.6 & 31.3 \\
transport and postal services & $60-63,64.1$ & 210 & 17.8 & 106 & 17.9 & 222 & 18.2 & 11.7 \\
electr. processing and telecom. & $72,62.2$ & 100 & 8.5 & 44 & 7.5 & 100 & 8.2 & 3.4 \\
consultancies & $74.1,74.4$ & 100 & 8.5 & 51 & 8.6 & 103 & 8.4 & 12.1 \\
technical services & $73,74.2,74.3$ & 142 & 12.1 & 76 & 12.9 & 152 & 11.7 & 10.7 \\
other business-rel. services & $70,71,74.5-.8,90$ & 279 & 23.7 & 141 & 23.9 & 292 & 23.9 & 20.3 \\
\hline total & & 1177 & 100 & 591 & 100 & 1222 & 100 & 100 \\
\hline
\end{tabular}

*German service firms with 5 and more employees in 1999.

Source: German Statistical Office, ZEW and own calculations

Table 9: Comparison of the different samples and the population by size classes

\begin{tabular}{lcccccccc}
\hline & \multicolumn{2}{c}{ full sample } & \multicolumn{2}{c}{ small sample } & ext. sample & \multicolumn{2}{c}{ population* } \\
\hline $\begin{array}{l}\text { size class } \\
\text { (\# employees) }\end{array}$ & $\#$ & $\%$ & $\#$ & $\%$ & $\#$ & $\%$ & $\%$ firms & $\%$ sales \\
\hline $5-9$ & 189 & 16.1 & 92 & 15.6 & 205 & 16.8 & 57.6 & 9.4 \\
$10-19$ & 189 & 16.1 & 107 & 18.1 & 206 & 16.9 & 24.0 & 9.9 \\
$20-49$ & 246 & 20.9 & 134 & 22.7 & 254 & 20.8 & 11.7 & 9.7 \\
$50-99$ & 156 & 13.3 & 88 & 14.9 & 156 & 12.8 & 3.5 & 6.9 \\
$100-199$ & 167 & 14.2 & 77 & 13.0 & 168 & 13.8 & 1.6 & 6.0 \\
$200-499$ & 102 & 8.7 & 50 & 8.5 & 102 & 8.3 & 1.0 & 7.0 \\
500 and more & 128 & 10.9 & 43 & 7.3 & 131 & 10.7 & 0.6 & 51.1 \\
\hline total & 1177 & 100 & 591 & 100 & 1222 & 100 & 100 & 100 \\
\hline
\end{tabular}

*German service firms with 5 and more employees in 1999.

Source: German Statistical Office, ZEW and own calculations 
Table 10: One-step results for the ICT-augmented production function

\begin{tabular}{lccccc}
\hline \multicolumn{5}{c}{ Dep. Variable: sales (logs) } \\
\hline inputs (logs) & $(3)$ & $(4)$ & $(5)$ & $(6)$ & $(7)$ \\
& GMM[-1] & GMM[-2] & SYS-GMM & SYS-GMM & SYS-GMM \\
1st diff. & 1st diff. & reference & not interact. & extended \\
\hline \hline labour & $0.515^{* * *}$ & 0.247 & $0.707^{* * *}$ & $0.737^{* * *}$ & $0.723^{* * *}$ \\
& $(0.174)$ & $(0.158)$ & $(0.073)$ & $(0.074)$ & $(0.075)$ \\
ICT capital & 0.053 & 0.069 & $0.114^{* *}$ & $0.081^{*}$ & 0.052 \\
& $(0.043)$ & $(0.041)$ & $(0.046)$ & $(0.049)$ & $(0.032)$ \\
non-ICT capital & 0.191 & 0.366 & $0.148^{* * *}$ & $0.155^{* * *}$ & $0.166^{* * *}$ \\
& $(0.198)$ & $(0.208)$ & $(0.046)$ & $(0.049)$ & $(0.046)$ \\
East-Germany & - & - & $-0.340^{* * *}$ & $-0.343^{* * *}$ & $-0.375^{* * *}$ \\
& & & $(0.051)$ & $(0.053)$ & $(0.049)$ \\
\hline observations & 3762 & 3762 & 4939 & 4939 & 5107 \\
firms & 1177 & 1177 & 1177 & 1177 & 1222 \\
R-square & 0.218 & 0.137 & 0.843 & 0.839 & 0.836 \\
\hline Wald statistics [df]: & & & & & \\
inputs & $14.7[3]$ & $13.9[3]$ & $446[4]$ & $441[4]$ & $494[4]$ \\
time and ind. dummies & $108[35]$ & $130[35]$ & $586[41]$ & $488[11]$ & $583[41]$ \\
\hline errors (p-values): & & & & & \\
AR(1) & 0.010 & 0.000 & 0.002 & 0.003 & 0.002 \\
AR(2) & 0.118 & 0.042 & 0.028 & 0.025 & 0.030 \\
\hline
\end{tabular}

$* * *, * *, *=$ significant on the 1,5 and 10 per cent level

Results are based on the one-step estimation corresponding to table 1. See footnotes on this table for further details. 
Table 11: One-step results for the regressions including human capital

\begin{tabular}{lcc}
\hline & \multicolumn{2}{c}{ Dep. Variable: sales (logs) } \\
\hline inputs (logs) & small & small w. skill \\
\hline \hline labour & $0.709^{* * *}$ & $0.707^{* * *}$ \\
& $(0.162)$ & $(0.108)$ \\
ICT capital & 0.051 & 0.077 \\
& $(0.0582$ & $(0.070)$ \\
non-ICT capital & 0.150 & 0.127 \\
& $(0.108)$ & $(0.086)$ \\
East-Germany & $-0.335^{* * *}$ & $-0.409^{* * *}$ \\
& $(0.085)$ & $(0.078)$ \\
\% university & - & $1.018^{* * *}$ \\
& & $(0.329)$ \\
\%vocational & - & $0.614^{* * *}$ \\
& & $0.217)$ \\
\hline observations & 1887 & 1887 \\
number of firms & 591 & 591 \\
R-square & 0.825 & 0.836 \\
Wald statistics[df] & & \\
inputs & $180[4]$ & $307[6]$ \\
time and ind. dummies & $339[34]$ & $350[34]$ \\
errors (p-values): & & \\
AR(1) & 0.024 & 0.016 \\
AR(2) & 0.106 & 0.063 \\
\hline
\end{tabular}

$* * *,{ }^{* *}, *=$ significant at the 1,5 and 10 per cent level

Results are based on the one-step SYS-GMM corresponding to table 11 and contain a constant and industry dummy variables interacted with year dummy variables. Heteroscedasticity consistent standard errors reported. 
Table 12: One-step results for the translog production function

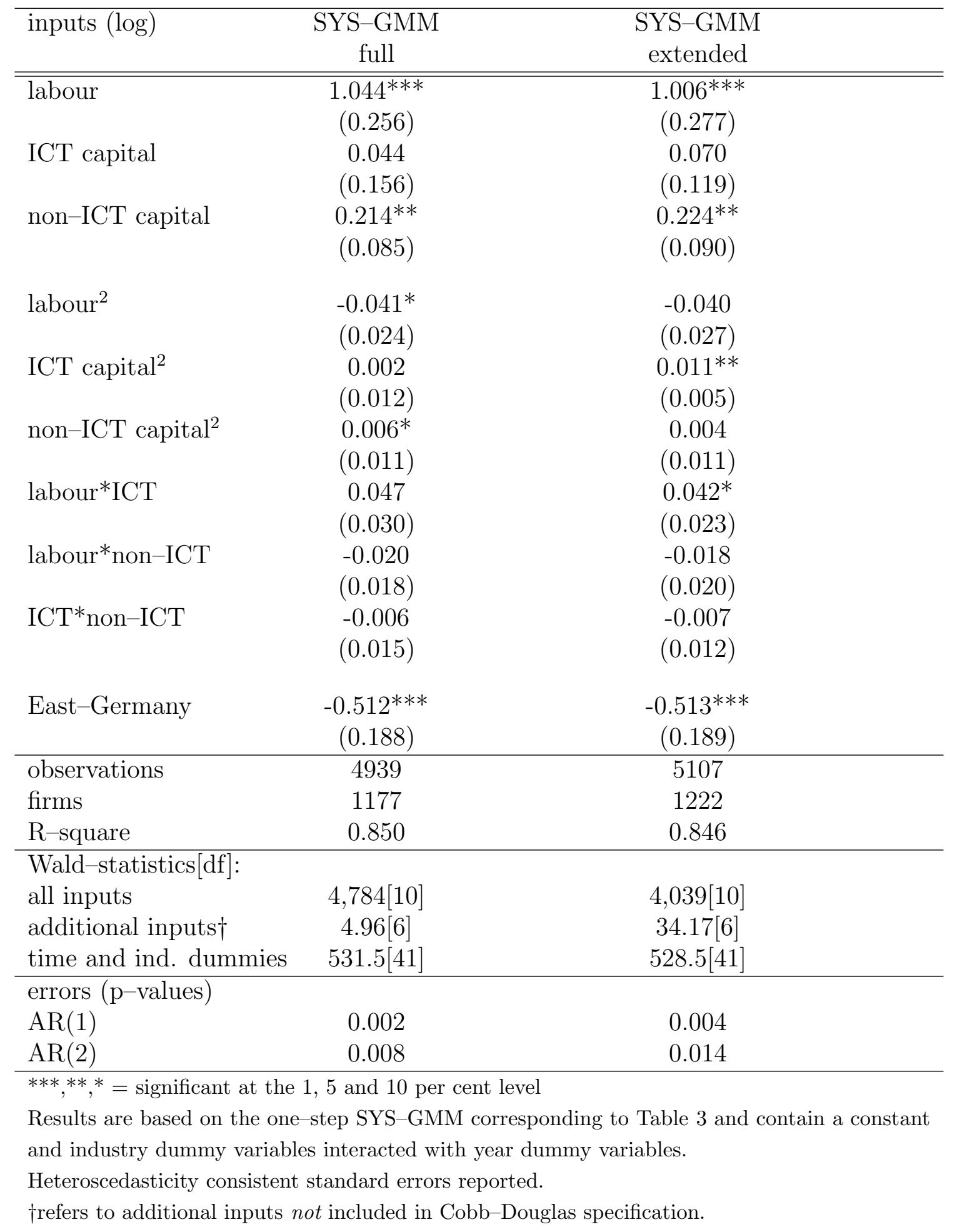

